\title{
PHYSICO-CHEMICAL AND ORGANOLEPTIC PROPERTIES OF COOKIES SUPPLEMENTED WITH CHEMICALLY MODIFIED STARCH
}

\author{
Ayesha Riaz ${ }^{1}$, Imran Pasha $^{1,},{ }^{*}$, Mian Kamran Sharif ${ }^{1}$ and Amer Jamil ${ }^{2}$ \\ ${ }^{1}$ National Institute of Food Science and Technology, University of Agriculture, Faisalabad-38040, Pakistan; \\ ${ }^{2}$ Department of Biochemistry, University of Agriculture, Faisalabad-38040, Pakistan \\ "Corresponding author's email: ipasha2001@uaf.edu.pk
}

\begin{abstract}
Present study investigated the effect of chemically (acid) modified starch on quality attributes of cookies. Cookies were supplemented with chemically modified starch at various levels $(5,10$ and $15 \%)$ and their physicochemical and sensory properties were evaluated. The results showed that cookies substituted with varying levels of chemically modified starch indicated width $(30.8-31.7 \mathrm{~cm})$, thickness $(5.2-5.4 \mathrm{~cm})$ and spread factor $(57.03-60.96)$. Color determined in term of $\mathrm{L}^{*}, \mathrm{a}^{*}$ and $b^{*}$ values were found as 67.44-70.25, 3.47-3.75 and 32.22-32.70, respectively. Chemical composition of cookies indicated moisture (2.10-3.21\%), ash (0.40-0.43\%), fat (21.10-22.93\%), fiber (0.083-0.107\%) and protein (5.41-5.69\%). Hardness values of fresh cookies ranged between 2.29 and $2.71 \mathrm{~kg}$. Our results showed that substitution of wheat flour with chemically modified starch up to $10 \%$ could be an effective approach to improve overall quality of cookies.
\end{abstract}

Keywords: Chemically modified starch, cookie quality, spread factor, hardness

\section{INTRODUCTION}

Native starches have limited food applications due to their sensitivity to $\mathrm{pH}$, heat and shear. Nonetheless, starches are modified to alter their properties like improvement in texture, viscosity, emulsification and shelf stability. Different starches exhibit diverse properties and used in food processing for several nutritional and aesthetic purposes (Falola et al., 2014). Starch modification changes its characteristics including water absorption, gelling, pasting and digestibility according to requirement. The properties of starch are modified through physical, chemical and enzymatic methods. From practical point of view, the starches are modified to improve physical, chemical and nutritional characteristics which might be useful for value added products. Generally, it can be used to increase stability towards different conditions i.e. extreme heat, shear, acidic condition; texture modification and to decrease or increase viscosity (Kumar and Prabhasankar, 2013).

Chemical modification of starch by acid hydrolysis consist of starch suspending in dilute solution of $\mathrm{HCl}$ or $\mathrm{H}_{2} \mathrm{SO}_{4}$ at certain temperature. Due to strong acid as well as heat, the cleavage of glycosidic linkages between the mono-saccharides in starch takes place (Yiu et al., 2008). It has been established that acid modification was found to alter the physicochemical attributes of starch such as improved solubility, reduced viscosity without impacting granular structure of starch. The degree of hydrolysis is influenced by starch consistency, $\mathrm{pH}$ value, temperature and duration of hydrolysis (Odeku et al., 2009).

Cookies are mainly characterized by high shortening and sugar level but, low final moisture (1-5\%), which is responsible for their microbiological stability (Mancebo $\mathrm{et} \mathrm{al}$., 2015). Cookie producers experience variations in wheat flour quality for different cookie formulations. It is well established that cookie quality is mainly associated with soft (low protein) wheat however, in Pakistan, we are lacking in a system to sort out different wheat varieties with respect to quality products. Since, variations in the quality characteristics of flour supplies are detrimental to cookie quality so, current study was based on the use of chemically modified starch to improve cookie baking quality of mixed wheat flour.

\section{MATERIALS AND METHODS}

Procurement of raw materials: For cookies preparation, wheat variety (AARI-11) was obtained from Wheat Research Institute, Ayub Agricultural Research Institute (AARI), Faisalabad, Pakistan. Commercially available mixed wheat flour was obtained from commercial flour mill. All the chemicals and reagents (analytical grade) were purchased from Merck (Merck KGaA, Darmstadt, Germany) and local market.

Chemical modification of starch: Corn starch was used to prepare Chemically Modified Starch (CMS) by adopting the method of Yousif et al. (2012) with slight modifications. For the purpose, $750 \mathrm{~g}$ corn starch was taken in a beaker and 375 $\mathrm{ml}$ distilled water was added. Then, $375 \mathrm{~mL}$ of diluted acid i.e., $0.1 \mathrm{~N} \mathrm{HCL}$ solution was added in the beaker containing a mixture of starch and distilled water. After that, $\mathrm{pH}$ was maintained to 7.0 with the help of an alkali $(1 \mathrm{~N} \mathrm{NaOH})$. After that, the starch was washed thrice with distilled water and filtered with Whatman Filter Paper No. 1. In addition, drying 
of neutralized starch was carried out for 24 hours at room temperature.

Wheat milling: Manually cleaned wheat grains were tempered at $15.5 \%$ moisture level for 24 hours at room temperature in order to equilibrate grain moisture. The amount of water for tempering was determined according to the method No. 26-95 given in AACC (2000). The tempered wheat grains were milled using Brabender Quadrumate Senior Mill (C.W. Brabender Instruments, Inc.) according to AACC (2000) method No. 26-21A. Break and reduction flour were blended to prepare straight grade flour (SGF).

Preparation of cookies: Cookies were made with straight grade flour obtained from AARI-11 (selected wheat variety) and mixed wheat flour (MWF) by substituting different levels of chemically modified starch at 5, 10 and 15\% levels following the method No. 10-50D as mentioned in AACC (2000). After removing trays from oven, the cookies were cooled for $20 \mathrm{~min}$. at room temperature and packed in polythene bags and evaluated for storage stability fortnightly for 30 days storage at room temperature.

Physical analyses: Width and thickness of six cookies was noted and spread factor was calculated by dividing width with thickness according to method No. 10-50D given in AACC (2000).

Chemical analyses: Chemical characteristics of cookies were determined i.e. moisture, ash, fat, fiber and protein content according to their respective methods described in AACC (2000) while, nitrogen free extract (NFE) was calculated by difference method.

Color: Color values of cookies were determined using color meter (Color Test II, Nehaus Neotech) following the method of Kara et al. (2005).

Hardness: Hardness value of cookies was determined according to the method used by Piga et al. (2005) through Texture Analyzer (TA-XT2, Plus, Stable Microsystems, Surrey, UK).

Organoleptic quality: Organoleptic quality of cookies was assessed according to the method of Meilgaard et al. (2007) using a 9 point hedonic scale. Cookies were presented randomly in coded white plate and water was supplied to rinse the mouth after each evaluation.

Statistical analysis: All analysis was carried out in triplicate and results were presented as mean \pm standard error. Significant differences within treatments were determined using Analysis of Variance (ANOVA) under completely randomized design however, beyond ANOVA contrast analysis was applied according to method described by Montgomery (2008) using different statistical software like SPSS version (version 13, 2004) and Minitab (version 11.2, 1996). Three factor factorial analysis was performed for storage data.

\section{RESULTS AND DISCUSSION}

\section{Physical properties of cookies:}

Spread factor: Cookie quality is mainly influenced by chemical constituents of flour, which absorb water as well as gluten quality and quantity. It has been reported earlier that large diameter or spread ratio are distinctive features of soft wheat with low protein and weak gluten network (Yamamoto et al., 1996; Pasha et al., 2009). Indeed, higher content of protein, damaged starch and arabinoxylan occur in hard and durum wheat cultivars, all these flour components absorb substantial amount of water and dwindled the biscuit spread during baking process (Pauly et al., 2013).

Pareyt et al. (2008) found a decline in cookies spread factor with an increment in protein and gluten content. Flour components which exhibit greater water absorption while, decreasing the amount of water available to dissolve sucrose in formula, which lead to higher initial dough viscosity and lower spread rate of cookies during baking (Hoseney and Rogers, 1994; Mancebo et al., 2015). Low protein content of flour is associated with low water absorption capacity and consequently, produce larger spread of cookies (Mancebo et al., 2015). High levels of damaged starch and pentosans enhance water absorption of flour and yield small cookie diameter (Moiraghi et al., 2013).

Supplementation of wheat flour with varying levels of chemically (acid) modified starch significantly $(\mathrm{p}<0.01)$ increased spread factor of cookies from 57.03 to 60.96 (Table 1). Among treatments, $\mathrm{T}_{6}$ produced largest (60.96) spread factor cookies whereas, $\mathrm{T}_{1}$ resulted cookies with least (57.03) spread. An increasing trend in spread factor was noted with the addition of CMS in wheat flour. A possible

Table 1. Physical properties of cookies supplemented with chemically modified starch.

\begin{tabular}{|c|c|c|c|c|c|c|}
\hline Treatments & Width (cm) & Thickness (cm) & Spread factor & L* value & $\mathbf{a}^{*}$ value & b* value $^{*}$ \\
\hline T1 (SWV:CMS; 95:5) & $30.8 \pm 0.76^{\mathrm{de}}$ & $5.4 \pm 0.16^{\mathrm{d}}$ & $57.03 \pm 1.25^{\mathrm{b}}$ & $68.37 \pm 1.82^{\mathrm{bcd}}$ & $3.62 \pm 0.10^{\mathrm{abc}}$ & $32.33 \pm 0.86^{\text {cde }}$ \\
\hline $\mathrm{T}_{2}$ (SWV:CMS; 90:10) & $31.0 \pm 0.72^{\mathrm{a}}$ & $5.3 \pm 0.15^{\mathrm{a}}$ & $58.49 \pm 1.30^{\mathrm{ab}}$ & $68.10 \pm 1.85^{\mathrm{cde}}$ & $3.69 \pm 0.11^{\mathrm{ab}}$ & $32.27 \pm 0.88^{\text {def }}$ \\
\hline $\mathrm{T}_{3}(\mathrm{SWV}: \mathrm{CMS} ; 85: 15)$ & $31.2 \pm 0.79^{c}$ & $5.2 \pm 0.14^{\mathrm{bc}}$ & $60.00 \pm 1.37^{\mathrm{c}}$ & $67.44 \pm 1.91^{\mathrm{def}}$ & $3.75 \pm 0.14^{\mathrm{a}}$ & $32.22 \pm 0.91^{\mathrm{def}}$ \\
\hline $\mathrm{T}_{4}$ (MWF:CMS; 95:5) & $30.9 \pm 0.76^{\mathrm{cd}}$ & $5.3 \pm 0.16^{\mathrm{a}}$ & $58.30 \pm 1.26^{\mathrm{a}}$ & $70.25 \pm 1.82^{\mathrm{abc}}$ & $3.47 \pm 0.09^{\mathrm{bcd}}$ & $32.70 \pm 0.85^{\mathrm{bcd}}$ \\
\hline $\mathrm{T}_{5}$ (MWF:CMS; 90:10) & $31.5 \pm 0.77^{\mathrm{bc}}$ & $5.3 \pm 0.16^{\mathrm{a}}$ & $59.43 \pm 1.27^{\mathrm{d}}$ & $69.90 \pm 1.66^{\mathrm{abc}}$ & $3.52 \pm 0.08^{\text {cde }}$ & $32.60 \pm 0.77^{\mathrm{cd}}$ \\
\hline $\mathrm{T}_{6}$ (MWF:CMS; 85:15) & $31.7 \pm 0.73^{\mathrm{b}}$ & $5.2 \pm 0.15^{\mathrm{b}}$ & $60.96 \pm 1.31^{\mathrm{c}}$ & $68.82 \pm 1.71^{\mathrm{bcd}}$ & $3.55 \pm 0.09^{\mathrm{abc}}$ & $32.44 \pm 0.80^{\mathrm{bcd}}$ \\
\hline
\end{tabular}

Values are reported as means of three measurements \pm standard error. Means sharing similar letter in a column are statistically nonsignificant (p>0.05). CMS: Chemically modified starch; MWF: Mixed wheat flour; SWV: Selected wheat variety 
explanation might be diluting effect of starch on flour protein. It could be reasoned here that acid-modified starch being sensitive to high temperature may have had reduced the viscosity of cookie dough. This fact may also be explained by the work of Sharma et al. (2016) who reported high spread ratio (13.2-20.2) of cookies prepared from gelatinizedretrograded starch (GRS) or extruded starch (ES) than control (12.5). They explained this fact relates to higher syrup formation and dilution of flour protein for cookies produced from GRS or ES. Moreover, the increase in spread ratio with substitution of GRS or ES was ascribed to decrease in dough consistency since, lower consistency tends to cause faster spread of cookies.

It is known that flour quality was improved by diluting wheat flour with starch at $10 \%$ level such as cornstarch, potato starch and arrowroot (Manley, 2011). Starch solution generally have tendency to alter the viscosity of other pastes and solutions as well and this approach is well exploited by food industries. However, native starch offers viscous, sticky and cohesive pastes upon heating and gels once these pastes are allowed to cool (Adebowale et al., 2005). In addition, native starch provides low resistance to shear stress. Native maize starch could be improved to acquire starch pastes with particular attributes, which can withstand extreme food processing parameters such as heat and acidic conditions.

Chemical modification is the most common method to modify starch intended to be used for texture improvement in various products. By modification, dough physical behavior like rheological and pasting properties can be altered (Liu et al., 2008). During acid hydrolysis, molecular weight of starch tends to decline while, crystallinity escalate (Zuo et al., 2014). Further, it decreases the amylose fraction and this reveals an increment in temperature of starch paste and enthalpy of gelatinization as stated by Lawal (2004). In general, application of aqueous solution of acids increase the consistency of gel and decrease paste viscosity likely due to de-polymerization of starch polymer (Ulbrich et al., 2015).

Color values: L* (lightness) values of cookies made by replacing wheat flour with chemically modified starch varied from 67.44 to 70.25 (Table 1). However, the cookies substituted with CMS at higher ratios had relatively dark color. A significant $(\mathrm{p}<0.01)$ increase in $\mathrm{a}^{*}$ (redness) values of cookies was observed from 3.47 to 3.75 . Different supplementation levels of CMS affected $b^{*}$ (yellowness) values and varied over a narrow range of 32.22-32.70. In this piece of work, cookies prepared with wheat flour: chemically modified starch (95:5) showed maximum $b^{*}$ value while, cookies (85:15) exhibited lowest. Nevertheless, the effect of CMS supplementation was different and it can be observed that $\mathrm{L}^{*}$ and $\mathrm{b}^{*}$ values dropped whereas, $\mathrm{a}^{*}$ values increased with a proportional rise of CMS in wheat flour. Present results are somewhat close to findings of Pareyt et al. (2011). This fact can be justified by the recent work of Pérez-Carrillo et al. (2017) who studied the impact of maize starch substitution on physicochemical and sensorial attributes for the development of gluten-free cookies. They adduced that flour substituted with $10 \%$ waxy maize starch resulted in darkest cookies with lowest $\mathrm{L}$ value (54.97) as compared to $5 \%$ substitution of waxy maize starch (58.83).

Maillard reactions involve complex reactions of reducing saccharides and amino acids. In absence of amino acids, sugars can also cause dark surface coloration by caramelization process. This relationship may possibly because of great availability of sugar for Maillard and caramelization, due to partial starch gelatinization (some amylose leaching) during baking (Sciarini et al., 2013). The efficiency of Maillard reaction is influenced by various factors such as chemical configuration of protein, amino acid fragments, presence of reducing saccharides as well as complex carbohydrates like starch (Chung et al., 2012).

Chemical properties: Statistical data presented in Table 2 indicated that the effect of the supplementation of CMS was highly significant $(\mathrm{p}<0.01)$ for most of chemical properties while, values were statistically similar for NFE content. Chemical composition of cookies revealed moisture, ash, fat, fiber, protein and NFE content ranged as 2.10-3.21, 0.400$0.430,21.10-22.93,0.083-0.107,5.41-5.69$ and 67.92$70.28 \%$, respectively. In present study, highest fat and fiber were reckoned in cookies substituted with CMS (15\%) however, lowest was observed in cookies (5\%).

This could be elucidated due to the supplementation of high level of starch into wheat flour, which contain low fat and fiber content. Tester et al. (2004) referred that lipid matrix of amylose content in cereal starch ranged between 0.15 and

Table 2. Chemical properties (\%) of cookies supplemented with chemically modified starch.

\begin{tabular}{|c|c|c|c|c|c|c|}
\hline Treatments & Moisture & Ash & Fat & Fiber & Protein & NFE \\
\hline $\mathrm{T}_{1}$ (SWV:CMS; 95:5) & $2.10 \pm 0.05^{\mathrm{a}}$ & $0.430 \pm 0.013^{\mathrm{b}}$ & $21.66 \pm 0.57^{\mathrm{cd}}$ & $0.083 \pm 0.003^{\mathrm{ab}}$ & $5.47 \pm 0.16^{\mathrm{ab}}$ & $70.28 \pm 1.99^{a}$ \\
\hline $\mathrm{T}_{2}(\mathrm{SWV}: \mathrm{CMS} ; 90: 10)$ & $3.21 \pm 0.10^{\mathrm{ab}}$ & $0.420 \pm 0.012^{\mathrm{c}}$ & $22.50 \pm 0.61^{\mathrm{a}-\mathrm{e}}$ & $0.093 \pm 0.005^{\mathrm{b}}$ & $5.44 \pm 0.15^{\mathrm{bc}}$ & $68.33 \pm 1.78^{\mathrm{a}}$ \\
\hline $\mathrm{T}_{3}(\mathrm{SWV}: \mathrm{CMS} ; 85: 15)$ & $2.70 \pm 0.08^{b}$ & $0.400 \pm 0.011^{\mathrm{d}}$ & $22.65 \pm 0.64^{\mathrm{abc}}$ & $0.103 \pm 0.007^{\mathrm{c}}$ & $5.41 \pm 0.12^{\mathrm{a}}$ & $68.74 \pm 1.79^{a}$ \\
\hline $\mathrm{T}_{4}(\mathrm{MWF}: \mathrm{CMS} ; 95: 5)$ & $2.99 \pm 0.09^{b c}$ & $0.410 \pm 0.011^{\mathrm{b}}$ & $21.10 \pm 0.55^{\mathrm{de}}$ & $0.087 \pm 0.004^{\mathrm{ab}}$ & $5.69 \pm 0.17^{\mathrm{c}}$ & $69.72 \pm 1.85^{\mathrm{a}}$ \\
\hline $\mathrm{T}_{5}$ (MWF:CMS; 90:10) & $3.20 \pm 0.13^{\mathrm{b}}$ & $0.430 \pm 0.013^{\mathrm{a}}$ & $22.70 \pm 0.59^{\mathrm{a}-\mathrm{d}}$ & $0.097 \pm 0.005^{\mathrm{bc}}$ & $5.66 \pm 0.17^{\mathrm{a}}$ & $67.92 \pm 1.84^{\mathrm{a}}$ \\
\hline $\mathrm{T}_{6}$ (MWF:CMS; 85:15) & $2.60 \pm 0.07^{\mathrm{bc}}$ & $0.417 \pm 0.009^{\mathrm{ab}}$ & $22.93 \pm 0.61^{\mathrm{abc}}$ & $0.107 \pm 0.007^{\mathrm{a}}$ & $5.63 \pm 0.16^{\mathrm{ab}}$ & $68.32 \pm 1.93^{\mathrm{a}}$ \\
\hline
\end{tabular}

Values are reported as means of three measurements \pm standard error. Means sharing similar letter in a column are statistically nonsignificant ( $>$ >0.05). CMS: Chemically modified starch; MWF: Mixed wheat flour; SWV: Selected wheat variety 
$0.55 \%$. Lipid matrix of cereal starch mainly comprised of phospholipids and free fatty acids; these are related to amylose. Fat play a crucial role in starch phase transitions influencing the rheological properties as described previously (Hernandez-Hernandez et al., 2011), amylose-lipid matrix influence heat transition and retrogradation of starch.

However, a reverse trend was noticed for protein content that tended to decrease with an increase in the level of CMS. Present study speculated that a decrease in protein content supports the view that dilution of wheat flour protein may have occurred due to supplementation of CMS in wheat flour at high levels. Further, a plausible reason is that low protein content was described in starch molecule $(0.6 \%)$ as referred by Alcazar-Alay and Meireles (2015). In addition, protein content of acid-thinned starch was found lowest $(0.42 \%)$ as compared to native starch $(0.73 \%)$ as reported earlier (Yousif et al., 2012). Cookies made with the supplementation of wheat flour with CMS (95:5) revealed highest protein. Similar values of fiber content were reported earlier by Olagunju and Ifesan (2013) for wheat flour cookies. Pareyt et al. (2011) found 2.4-2.6\% moisture in cookies made with flour substituted with starch by 10 to $40 \%$. Ojinnaka et al. (2013) reported that protein content decreased from 9.51 to 7.59 by adding $10 \%$ crude African breadfruit starch and marginally increased to 7.82 with $20 \%$ crude starch into cookies.

Hardness values: Statistical analysis revealed highly significant effect $(\mathrm{p}<0.01)$ of chemically modified starch on hardness values of cookies. Figure 1 represents hardness of fresh cookies made by supplementing wheat flour with CMS ranged as $2.29-2.71 \mathrm{~kg}$. At 0 day, greater force $(2.71 \mathrm{~kg}$ ) was required to break $\mathrm{T}_{3}$ cookies whereas, smaller $(2.29 \mathrm{~kg})$ was recorded for $\mathrm{T}_{4}$. Present study established an increasing trend for cookies hardness with an increase in CMS substitution to wheat flour. Although, the dilution of protein occurs by substitution of starch even though, higher breaking strength of cookies with increasing the substitution level underscore that there are some other factors, which are responsible for the more structured network that is likely due to high levels of flour protein (Laguna et al., 2011). Gaines (1990) described that gluten protein is not functionally inert in such cookie doughs, particularly during baking. As cookie dough is undeveloped during baking, even though a protein network consisting of glutenin and gliadin fractions is formed by the covalent bonding of sulfhydryl (-SH) groups. Additionally, internal structure of cookie and intrinsic material characteristics are generally influenced by protein network and together, these then impact the break strength of cookies (Pareyt et al., 2010). In this context, Doescher et al. (1987) employed scanning electron microscope and evidenced the presence of a well-formed gluten network that surrounds ungelatinized starch molecules. It is known that cross-link of gluten protein occurs by a mechanism of SH/SS exchange leading to copolymerization of gliadin and glutenin fractions into an assumed gluten matrix as stated by Lagrain et al. (2008).

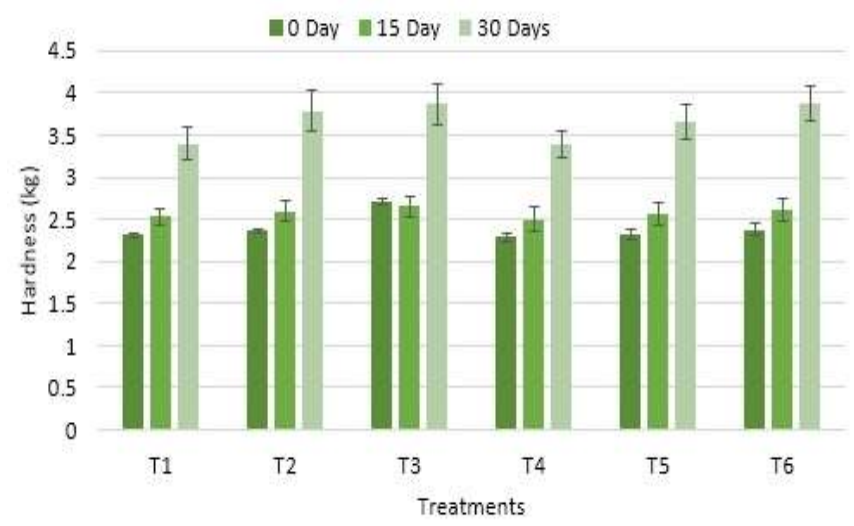

Figure 1. Hardness of cookies supplemented with chemically modified starch.

Storage studies also revealed similar increasing trend from 2.50 to $2.85 \mathrm{~kg}$ (15 days) and 3.40 to $3.88 \mathrm{~kg}$ (30 days). PérezCarrillo et al. (2017) also experienced the same storage trend for texture parameters of all cookies supplemented with different types and levels of starches, and force was found to be significantly increased for all cookies except pregelatinized cross-link maize starch (at 10\% level) during storage of 5 days at room temperature. The evidence of these variations stem from the fact of the differences in glutenstarch interaction in wheat flour and degree of starch retrogradation (Pacheco and Techeira, 2009). However, in contrast to present results Qaisrani et al. (2014) found that hardness was decreased during storage for cookies supplemented with psyllium husk. Pareyt et al. (2011) reported 11.6-18.6N break strength of wheat cookies substituted with 10-40\% starch.

Organoleptic quality: Quality assessment of fresh cookies and after 30 days was evaluated separately. Overall acceptability scores ranged from 6.75 to 7.50 for fresh cookies supplemented with CMS (Figure 2). At 0 day, $\mathrm{T}_{4}$ cookies were highly acceptable and a decreasing trend was observed with the addition of CMS into wheat flour. This implies that wheat flour could be supplemented with CMS up to $10 \%$ for cookies without affecting overall quality. However, storing cookies for 15 and 30 days significantly $(\mathrm{p}<0.01)$ influenced overall acceptability as 6.13-7.25 and 5.88-7.00, respectively. Storage studies revealed a significant effect of CMS on overall acceptability and cookies attained comparatively lower color scores as compared to their fresh counterparts. Ojinnaka et al. (2009) used acid and enzymatic methods to modify cocoyam starch and substituted these starch samples with wheat flour for the preparation of cookies. After 60 days storage, cookies with 5 and $10 \%$ substitution were found most acceptable. 


\section{Cookies supplemented with chemically modified starch}

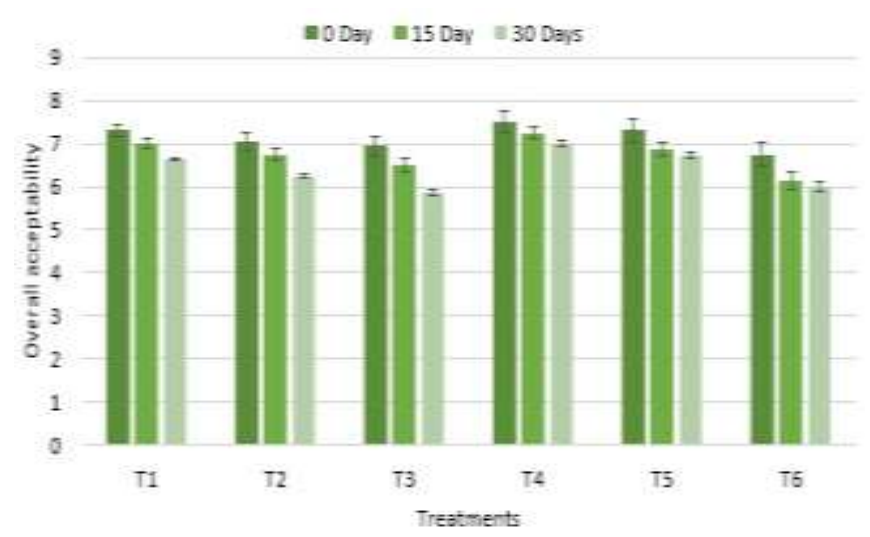

Figure 2. Overall acceptability of cookies supplemented with chemically modified starch.

Conclusion: The authors infer that addition of chemically modified starch significantly increased spread factor of cookies produced from mixed wheat flour, which were comparable to those made with wheat variety. However, supplementation at higher levels produced cookies with dark color and hard texture. Also, storing cookies for one month had a significant effect on overall acceptability. Addition of chemically modified starch is recommended for the improvement of baking quality of cookies at $10 \%$ level and level above $10 \%$ level had adverse impact on cookies characteristics.

\section{REFERENCES}

AACC (American Association of Cereal Chemists). 2000. Approved methods of American Association of Cereal Chemists. 10th ed. Amer. Assoc. Cereal Chem., St. Paul, Minnesota, USA.

Adebowale, K.O., B.I. Olu-Owolabi, E.K. Olawumi and O.S. Lawal. 2005. Functional properties of native, physically and chemically modified breadfruit (Artocarpus artilis) starch. Ind. Crops Prod. 21:343-351.

Alcázar-Alay, S.C. and M.A.A. Meireles. 2015. Physicochemical properties, modifications and applications of starches from different botanical sources. Food Sci. Technol. Campinas. 35:215-236.

Chung, S.Y., S.H. Han, S.W. Lee and C. Rhee. 2012. Effect of Maillard reaction products prepared from glucoseglycine model systems on starch digestibility. Starch. 64:657-664.

Doescher, L.C., R.C. Hoseney, G.A. Milliken and G.L. Rubenthaler. 1987. Effect of sugars and flours on cookie spread evaluated by time-lapse photography. Cereal Chem. 64:163-167.

Falola, A.O., O.P. Olatidoye, S.O. Adesala and M. Amusan. 2014. Modification and quality characteristics of Cocoyam starch and its potential for chin-chin production. Pak. J. Nutr. 13:768-773.
Gaines, C.S. 1990. Influence of chemical and physical modification of soft wheat protein on sugar-snap cookie dough consistency, cookie size, and hardness. Cereal Chem. 67:73-77.

Hernandez-Hernandez, E., C.A. Avila-Orta, B.S. Hsiao, Castro-Rosas, J., J.A. Gallegos-Infante, J. MoralesCastro, L.A. Ochoa-Martínez and C.A. Gómez-Aldapa. 2011. Synchrotron X-ray scattering analysis of the interaction between corn starch and an exogenous lipid during hydrothermal treatment. J. Cereal Sci. 54:69-75.

Hoseney, R.C. and D.E. Rogers. 1994. Mechanism of sugar functionality in cookies. In: H. Faridi (ed.), The Science of Cookie and Cracker Production. Chapman and Hall, New York, USA.

Kara, M., D. Sivri and H. Koksel. 2005. Effects of high protease-activity flours and commercial proteases on cookie quality. Food Res. Int. 38:479-486.

Kumar, S.B. and P. Prabhasankar. 2013. Low glycemic index ingredients and modified starches in wheat based food processing: A review. Trends Food Sci. Technol. 35:3241.

Lagrain, B., B.G. Thewissen, K. Brijs and J.A. Delcour. 2008. Mechanism of gliadin-glutenin cross-linking during hydrothermal treatment. Food Chem. 107:753-760.

Laguna, L., A. Salvador, T. Sanz and S.M. Fiszman. 2011. Performance of a resistant starch rich ingredient in the baking and eating quality of short-dough biscuits. LWTFood Sci. Technol. 44:737-746.

Lawal, O.S. 2004. Composition, physicochemical properties and retrogradation characteristics of native, oxidised, acetylated and acid-thinned new cocoyam (Xanthosoma sagittifolium) starch. Food Chem. 87:205-218.

Liu, Z., Y. Li, F. Cui, L. Ping, J. Song, Y. Ravee, L. Jin, Y. Xue, J. Xu, G. Li, Y. Wang and Y. Zheng. 2008. Production of octenyl succinic anhydride-modified waxy corn starch and its characterization. J. Agric. Food Chem. 56:11499-11506.

Mancebo, C.M., J. Picon and M. Gomez. 2015. Effect of flour properties on the quality characteristics of gluten free sugar-snap cookies. LWT-Food Sci. Technol. 64:264269.

Manley, D. 2011. Manley's Technology of Biscuits, Crackers and Cookies, $4^{\text {th }}$ Ed. Woodhead Publishing Limited, Cambridge, UK.

Meilgaard, M.C., G.C. Civille and B.T. Carr. 2007. Sensory Evaluation Techniques, $4^{\text {th }}$ Ed. CRC Press L.L.C., New York, USA.

Moiraghi, M., L. Vanzetti, L. Pflüger, M. Helguera and G.T. Pérez. 2013. Effect of high molecular weight glutenins and rye translocations on soft wheat flour cookie quality. J. Cereal Sci. 58:424-430.

Montgomery, D.C. 2008. Experiments with a single factor: The analysis of variance. In: Design and Analysis of Experiments, $8^{\text {th }}$ Ed. John Wiley \& Sons, Inc. 
Odeku, O.A., W. Schmid and K.M. Picker-Freyer. 2009. Characterization of acid-modified Dioscorea starches as direct compression excipients. Pharm. Dev. Technol. 14:259-270.

Ojinnaka, M.C., E.N.T. Akobundo and M.O. Lwe. 2009. Cocoyam starch modification effects on functional, sensory and cookie quality. Pak. J. Nutr. 8:558-567.

Ojinnaka, M.C., F.A. Anyanwu and A. Ihemeje. 2013. Nutritional evaluation of cookies produced from African breadfruit (Treculia africana) starch and wheat flour. Int. J. Agric. Food Sci. 3:95-99.

Olagunju, A.I. and B.O.T. Ifesan. 2013. Nutritional composition and acceptability of cookies made from wheat flour and germinated sesame (Sesamum indicum) flour blends. Brit. J. Appl. Sci. Technol. 3:702-713.

Pacheco, E. and N. Techeira. 2009. Propiedades qu'imicas y funcionales del almid'on nativo y modificado de name (Dioscorea alata). Interciencia. 34:280-285.

Pareyt, B., B.V. Steertegem, K. Brijs, B. Lagrain and J.A. Delcour. 2010. The impact of redox agents on sugar-snap cookie making. J. Cereal Sci. 52:192-199.

Pareyt, B., E. Wilderjans, H. Goesaert, K. Brijs and J.A. Delcour. 2008. The role of gluten in a sugar-snap cookie system: a model approach based on gluten-starch blends. J. Cereal Sci. 48:863-869.

Pareyt, B., M. Goovaerts, W.F. Broekaert and J.A. Delcour. 2011. Arabinoxylan oligosaccharides (AXOS) as a potential sucrose replacer in sugar-snap cookies. LWTFood Sci. Technol. 44:725-728.

Pasha, I., F.M. Anjum and M.S. Butt. 2009. Biochemical characterization of spring wheats in relation to grain hardness. Int. J. Food Prop. 12:910-928.

Pauly, A., B. Pareyt, M.A. Lambrecht, E. Fierens and J.A. Delcour. 2013. Flour from wheat cultivars of varying hardness produces semi-sweet biscuits with varying textural and structural properties. LWT-Food Sci. Technol. 53:452-457.

Pérez-Carrillo, E., A. Frías-Escobar, K. Gutiérrez-Mendívil, S. Guajardo-Flores and S.O. Serna-Saldívar. 2017. Effect of maize starch substitution on physicochemical and sensory attributes of gluten-free cookies produced from
Nixtamalized flour. J. Food Process 1-6. https://doi.org/10.1155/2017/6365182

Piga, A., P. Catzeddu, S. Farris, T. Roggio, A. Sanguinetti and E. Scano. 2005. Texture evolution of "Amaretti" biscuits during storage. Eur. Food Res. Technol. 221:387-391.

Qaisrani, T.B., M.S. Butt, S. Hussain and M. Ibrahim. 2014. Characterization and utilization of Psyllium husk for the preparation of dietetic cookies. Int. J. Mod. Agric. 3:8191.

Sciarini, L.S., F. Van Bockstaele, B. Nusantoro, G.T. Pérez and K. Dewettinck. 2013. Properties of sugar-snap cookies as influenced by lauric-based shortenings. J. Cereal Sci. 58:234-240.

Sharma, S., N. Singh and M. Katyal. 2016. Effect of gelatinized-retrograded and extruded starches on characteristics of cookies, muffins and noodles. J. Food Sci. Technol. 53:2482-2491.

Tester, R.F., J. Karkalas and X. Qi. 2004. StarchComposition, fine structure and architecture. J. Cereal Sci. 39:151-165.

Ulbrich, M., I. Wiesner and E. Floter. 2015. Molecular characterization of acid-thinned wheat, potato and pea starches and correlation to gel properties. Starch/Starke. 66:1-14.

Yamamoto, H., S.T. Worthington, G. Hou and P. Ng. 1996. Rheological properties and baking qualities of selected soft wheats in the United States. Cereal Chem. 73:215221.

Yiu, P.H., S.L. Loh, A. Rajan, S.C. Wong and C.F.J. Bong. 2008. Physicochemical properties of sago starch modified by acid treatment in alcohol. Am. J. Appl. Sci. 5:307-311.

Yousif, E.I., M.G.E. Gadallah and A.M. Sorour. 2012. Physico-chemical and rheological properties of modified corn starches and its effect on noodle quality. Ann. Agric. Sci. 57:19-27.

Zuo, Y., J. Gu, H. Tan, Z. Qiao, Y. Xie and Y. Zhang. 2014. The characterization of granule structural changes in acid-thinning starches by new methods and its effect on other properties. J. Adhes. Sci. Technol. 28:479-489. 